\title{
Recurrence of atretic parietal cephalocele in adult: a case report and review of literature
}

\author{
Ö. Ertuğrul ${ }^{1}$, E. Çiçekçi², M.C. Tuncer ${ }^{3}$, M.U. Aluçlu4 \\ ${ }^{1}$ Department of Radiology, Private Bağlar Hospital, Diyarbakır, Turkey \\ 2Department of Physiotherapy, University of Health Sciences, Gazi Yaşargil Education and Research Hospital, \\ Diyarbakır, Turkey \\ ${ }^{3}$ Department of Anatomy, Faculty of Medicine, University of Dicle, Diyarbakır, Turkey \\ ${ }^{4}$ Department of Neurology, Faculty of Medicine, University of Dicle, Diyarbakır, Turkey
}

[Received: 19 September 2017; Accepted: 23 October 2017]

\begin{abstract}
Common presentation of atretic parietal cephalocele is mostly seen in infants and young children. It is a palpable midline parietal soft tissue mass which is thought to represent involuted true cephalocele (meningocele or encephalocele) connected to dura mater via a fibrous stalk. Atretic parietal cephalocele is associated with increased incidence of intracranial anomalies. Parietal cephaloceles comprise about $1 \%$ of all cerebrospinal congenital malformations and $10 \%$ of cephaloceles. We report here the case of an atretic parietal cephalocele with no associated brain malformations in adult. (Folia Morphol 2018; 77, 3: 591-596)
\end{abstract}

Key words: atretic cephalocele, encephalocele, straight sinus, brain herniation, adult, neuroradiology

\section{INTRODUCTION}

Atretic parietal cephalocele (APC), also known as atretic cephalocele $(A C)$, refers to small subscalp lesions that consist of dura, fibrous tissue, neural and glial rests [41]. Cephaloceles typically present at birth and usually come to medical attention within the first week of life. They are categorised according to the site of the skull defect. They are often sporadic, but the occipital form may be part of a genetic malformation syndrome. Most cephaloceles and associated malformations are treated by surgery. The prognosis depends on the site, content of the sac, operability, hydrocephalus, and other associated malformations. Cephaloceles are designated as: occipito-cervical type, if the skull defect involves the occipital bone, foramen magnum and the posterior arches of C1, C2, etc.; occipital type, if the defect lies between foramen magnum and the lambda; parietal type, if the defect lies between the lambda and the bregma; lateral type, if the defect lies along the coronal or lambdoid sutures as far inferiorly as the anterolateral and posterolateral fontanelles; interfrontal type, if the defect lies between the bregma and the nasal bones; temporal, if the defect lies along the superior surface of the petrous pyramid; fronto-ethmoidal type (synonym: sincipital), if the defect lies between the nasal bones and the ethmoid bone; spheno-orbital type, if the ostium for the herniation involves the optic foramen, the superior orbital fissure, or a defect in the orbital wall; spheno-maxillary type, if the ostium for the herniation extends through the superior orbital fissure and the inferior orbital fissure into the pterygopalatine fossa; nasopharyngeal type, if the defect lies within the ethmoid, sphenoid, or basioccipital bones [48]. Martinez-Lage et al. [32-34] classified AC into two types: Type 1 consisting of arachnoid tissue with clus-

Address for correspondence: Prof. M.C. Tuncer, PhD, Department of Anatomy, Faculty of Medicine, University of Dicle, Diyarbakır, Turkey, tel: +90 412 2488001, ext. 4539 (Faculty room), fax: +90 532 2744926, e-mail: drcudi@hotmail.com 

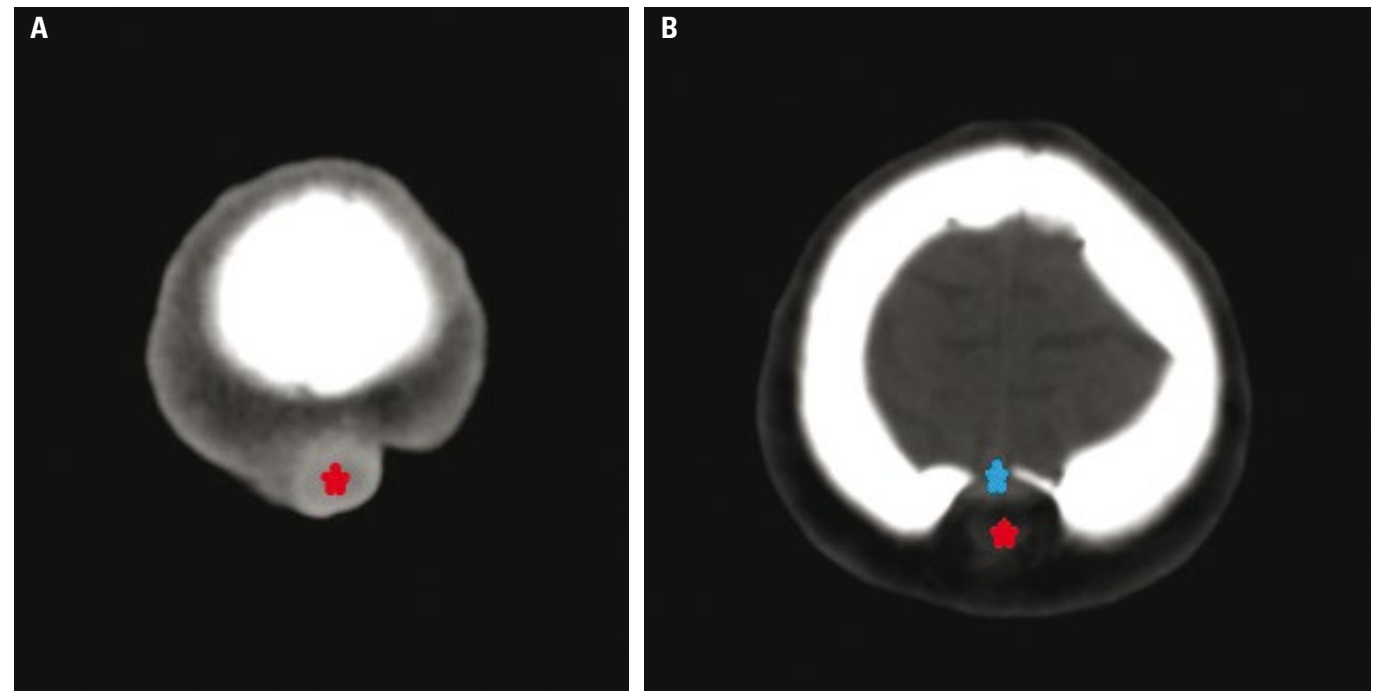

Figure 1. A. A midline small subscalp mass on unenhanced computed tomography (red asterisk); B. A small bone defect (blue asterisk) at the posterior midline of parietal bone which was connected to the scalp mass (red asterisk).

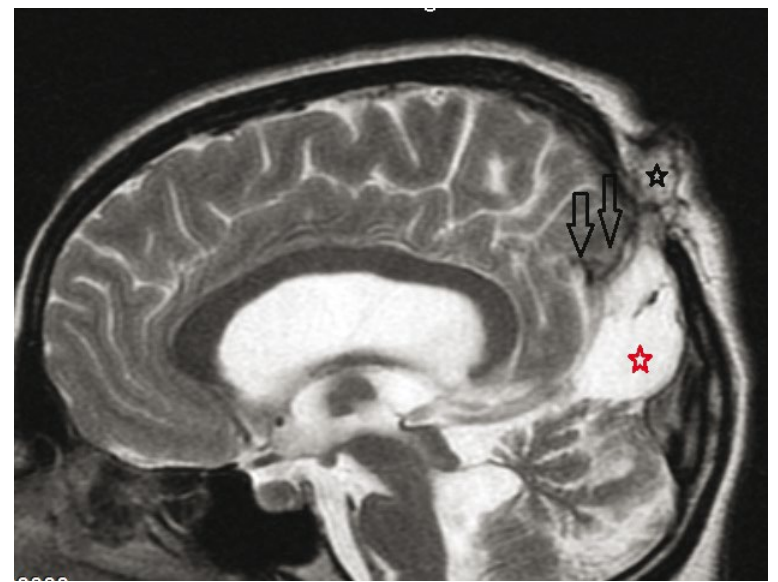

Figure 2. Sagittal T2W images demonstrated flow void extending posterosuperiorly representing embryonic position of the vertical straight sinus (long black arrows), prominent superior cerebellar recess (red asterisk) and a small subscalp mass (black arrow).

ters of anomalous blood vessels limited to the stalk of the lesion, Type 2 consisting of meningeal tissue intermingled with dermal and fibrous tissue, as well as clusters of anomalous blood vessels, extending as a net, and ectopic neural or glial elements. In according to classification of Martinez-Lage et al. [32-34], our case can be evaluated as type 1 , because, it is clear that soft tissue mass is localised under the scalp (Figs. 1, 2). In addition, Peters et al. [43] detected subscalp lesions that are covered by skin. APC differ from the other cephaloceles as defined by Yokota et al. [56] by having small, non-cystic, flat or nodular lesions arising in the vertex midline. Magnetic resonance imaging (MRI) and computed tomography (CT) are the best imaging tools to evaluate the possible concomitant central nervous system (CNS) anomalies in patients with ACs. Pathological classification of cephaloceles is known as meningocele (leptomeninges and cerebrospinal fluid [CSF]), meningoencephalocele (leptomeninges, CSF and brain), meningoencephalocystocele (leptomeninges, CSF, brain and ventricles), AC (small nodule of fibrous fatty tissue), and gliocele (CSF lined by glial tissue) $[7,39]$. APC are associated with anomalies of Chiari II and III malformations, corpus callosum agenesis and Dandy-Walker malformation [32, 38].

The aetiology of cephalocele in the majority of cases is not known. Like neural tube defects, cephalocele is considered to be multifactorial in origin and a variety of genetic and environmental factors have been implicated in its aetiology $[12,23]$. The influence of genetic factors is suggested in some cases of occipital cephaloceles that are associated with genetic syndromes such as Knobloch syndrome [46], Meckel syndrome [40], and other rare syndromes [14]. Moreover, the significance of the role of genetic factors in occipital cephalocele may be supported by its increased incidence in families with previous neural tube defects [51]. The incidence of cephaloceles is $0.8-3.0$ per 10,000 births $[20,28,48]$. Thus, cephaloceles are approximately 10 times less common than myelomeningoceles. Mealey et al. [36] found 60 encephaloceles and 559 myelomeningoceles among 76,280 admissions to a children's hospital over 
a 20-year period. The different types of cephaloceles show strong geographic variation, substantial differences in incidence and form with race and sex, as well as different associations with neural tube defects: among white populations in Europe and North America, occipital cephaloceles constitute $66-89 \%$ of all cephaloceles $[13,48]$. In Southeast Asia, sincipital cephaloceles are more common [50]. Among white Australians, $66.7 \%$ of cephaloceles are occipital and only $2.2 \%$ sincipital, whereas among aboriginal Australians, $50 \%$ of cephaloceles are sincipital [48]. Igbos Nigerians have a similar, disproportionately high incidence of sincipital cephaloceles. It is clearly seen that genetic origin is important to define different types of cephaloceles. The male to female ratios are $1 /(2.0-$ -2.7), approximately $2: 1$, and approximately $1.5 / 1$, respectively. Occipital and parietal cephaloceles appear to be related to neural tube defects [48]. Mealey et al. [36] reported that $7 \%$ of children with occipital encephalocele show concurrent myelomeningocele. Three percent of patients with (cervico-) occipital cephalocele have diastematomyelia and $3 \%$ have a second cephalocele in the parietal region the same as our in-patient [48].

The diagnosis is based on radiological findings. Ultrasonography is of great value in determining the size and content of the cephalocele, the size and shape of the skull, the extent of bony defect, and the size and shape of the ventricular system and its relation to the cephalocele sac in both the foetus and the neonate $[11,27]$. This method is particularly useful in the prenatal diagnosis of cephalocele and associated malformations [8, 22, 44, 45, 47]. In the postnatal period, the CT scan and MRI provide us with the most useful information regarding anatomic structure in delineating various brain and skull abnormalities associated with the occipital cephalocele $[52,57]$.

We report here a case of a recurrent APC, which is rarely seen, with characteristic imaging features in adult. We described all types of $A C$ in detail and discussed pathological classifications of cephalocele in this review.

\section{CASE REPORT}

A 25-year-old man who had been operated for a subscalp mass when he was 5 year old. Twenty years later, he was admitted again to neurosurgery clinic for recurrence of the mass on the operation site at a rural hospital. The pathology of mass was normal in his report, and excision of superficial mass was misdiagnosed as dermoid cyst. Over 2 years, the patient had been complaining of gradually increasing mass on the operation site. Therefore, the patient was admitted to neurosurgery clinic in our university. In routine radiological examinations, CT and MRI of the brain were performed for characterisation of the mass. A small cranial defect at the posterior midline of parietal bone which was connected to the scalp mass was observed on noncontrast CT (Fig. 1A, B). The lesion was hyperintense on $\mathrm{T} 2 \mathrm{~W}$ and hypointense on T1W images. Sagittal T2W images demonstrated a bony defect involving the underlying parietal bone. T2W sagittal and axial images showed flow void extending posterosuperiorly representing embryonic position of the vertical straight sinus and prominent superior cerebellar recess (Fig. 2).

Based on CT and MR imaging findings, we present here recurrent atretic parietal cephalocele in adult which is not associated with malformations of APC (Chiari II and III malformation, corpus callosum agenesis and Dandy-Walker malformation etc.).

\section{DISCUSSION}

Atretic cephaloceles are formes frustes of cephaloceles that are characterised by a small, noncystic, flat, or nodular lesion situated in the midline of the scalp, either near to vertex (parietal form) or just cephalic to the external occipital protuberance (occipital form) [56]. The prognosis for patients with a cephalocele depends primarily on site, content of the sac, operability, hydrocephalus, and additional malformations [16, 25, 29-31, 34, 36, 48, 55].

Historically, the term cephalocele, in a restrictive sense, is defined as a protrusion of part of the cranial contents through a congenital opening in the cranium, typically covered with skin or mucous membrane. However, in a broad sense of the term, it has been used to include also the acquired traumatic and nontraumatic forms. The condition was first described by Forestus in 1590 [6]. The first monograph on the subject was written by Corvenius in 1749 , and was followed by a long series of papers on the various aspects of the disorder including the clinical features, pathology, incidence, pathogenesis, and treatment [6]. Ballantyne's comprehensive morphologic study contributed significantly to the understanding of the pathology of the lesion and its classification. A variety of terms have been used to describe this congenital lesion. They include "hernia cerebri," "hydranencephalocele," "encephalocele," "cephalocele," "cranium 
bifidum," "exencephalus," and "exencephalocele." The term "hernia cerebri" should be reserved for acquired lesions. "Hydranencephalocele" is confused with "hydranencephaly," which represents a different congenital lesion [21]. "Cranium bifidum" describes only the bony defect. "Exencephalus" is confused with "exencephaly," which represents an earlier stage of anencephaly [51]. The term "exencephalocele" is also confusing and should be avoided. Among these, the term "cephalocele" appears to be the most appropriate $[6,17]$. This term denotes two specific types of lesions: herniation of brain tissue with the overlying meninges through a cranial defect (meningoencephalocele or encephalocele); and herniation of meninges without brain tissue (cranial meningocele). Today, the terms cephalocele and encephalocele are used almost interchangeably in the neurosurgical literature. Diminutive forms of cephalocele appear as small noncystic subcutaneous nodules and are often of no clinical significance. These forms have been referred to under a variety of terms including "occult," "rudimentary," "abortive," "sequestrated," and "atretic" encephalocele or meningocele of scalp $[34,41,56]$. The other terms used for these subcutaneous lesions include "brain tissue heterotopia," "glial heterotopia," and "glioma" in scalp and nasal regions $[15,53]$.

Atretic encephalocoele was first reported in 1972 by James and Lassman [26], who defined it as a degenerative form of encephalocele. Its reported incidence is $4-17 \%$ of all the encephaloceles [56] and parietal location comprises $40-50 \%$ of cases. It has been rarely reported in adults [2]. Parietal cephaloceles are very rarely seen ( $1 \%$ of all cerebrospinal malformations and $10 \%$ of cephaloceles [43] and if they are congenital, they are usually associated with many anomalies such as corpus calosum agenesis, Chiari II, Dandy-Walker malformation. McLaurin [35], in his series of parietal cephalocele, noted that 3 of 4 patients with encephalocele had major developmental brain abnormalities and died; the fourth patient remained alive but with severe psychomotor retardation associated with phenylketonuria. Of 7 cases of parietal meningocele, only 2 had brain abnormality that consisted of agenesis of the corpus callosum, and none of them died during 9 months to 10 years of follow-up. Simpson et al. [48] noted that among 8 cases of parietal encephalocele that were followed up, 7 were severely handicapped, but none of the 3 parietal meningocele patients showed significant disability. In a study by Patterson et al. [41], 5 of 8 patients had parietal $A C$ as an isolated anomaly, while 3 patients had other brain abnormalities, with the most common additional finding being ventriculomegaly.

Generally, venous anomalies accompany this disease, and most of these cases have benign clinical findings. Causation of abnormal venous drainage in the great vein of Galen, the straight sinus and the superior sagittal sinus may be secondary, through interaction with a developmentally pre-existing encephalocele $[24,37]$. Regardless of the mechanism of $A C$ formation, vertical embryonic positioning of the straight sinus has frequently been identified in these lesions and deserve to be mentioned both as a marker of the timing of the embryologic insult and as a clue to radiologic diagnosis "hallmark imaging sign". During stage 7a of cranial venous development, corresponding to a crown-rump length of approximately $80 \mathrm{~mm}$, the straight sinus is nearly vertical in a ventral-dorsal plane. We also determined that the straight sinus was coursing vertically and prominent superior cerebellar recess in T2W sagittal and axial images (Fig. 2). Various malformations may be seen in APC, especially in Chiari II and III malformations, corpus callosum agenesis and Dandy-Walker malformations $[19,37]$. Other associated malformations include ventriculomegaly, cystic malformations, heterotopias of the posterior fossa. In this case, we have not seen any concomitant anomaly except for the parietal location and typical imaging findings.

The bone deformities of $A C$ could be seen on plain X-rays $[5,10]$. However, not all patients with $A C$ present with bony defects or scalp lesions [18]. MRI and $\mathrm{CT}$ are the best imaging modalities to evaluate the possible concomitant CNS anomalies in patients with AC. The bony margins of an AC could be oval or elongated in shape, and taper from inside to outside. The cystic content is isodense to the cerebrospinal fluid or slightly hyper-dense to the brain parenchyma in $C T$ [1, 5, 32]. The cyst is hypointense in T1- and hyperintense in T2-weighted MRI scans [3, 9]. The AC content enhances if a vascular structure is present inside it [1]. We observed that the lesion was hyperintense on T2W and hypointense on T1W images as the same results in other studies $[3,9]$.

\section{CONCLUSIONS}

In conclusion, we present here recurrent APC, which is not associated with brain malformations in adult. The incidence of APC is rarely seen in adults. 
A few case reports of APC in adults have been reported in literatures so far $[1,2,4,5,24,42,49]$. The most important diagnostic workups include ultrasonography for prenatal diagnosis and MRI and $\mathrm{CT}$ in children and adults $[27,54]$. The presence of straight sinus coursing vertically and prominent superior cerebellar recess is detected through radiological findings. Especially, the straight sinus coursing vertically is the most important landmark to radiologically define APC.

\section{REFERENCES}

1. Abubacker S, Lakhkar B, Shetty D, et al. Adult atretic parietal cephalocele. Neurol India. 2002; 50(3): 334-336, indexed in Pubmed: 12391465.

2. Ahmet Ş, Miktat K, Can HY, et al. Atretic cephalocele in adults. Acta Neurochir. 2011; 153(11): 2275-2277, doi: 10.1007/s00701-011-1119-x.

3. Arishima H, Neishi H, Kikuta KI. Occipital cephalocele with neural crest remnants? Radiological and pathological findings in a newborn boy. Childs Nerv Syst. 2016; 32(6): 1141-1144, doi: 10.1007/s00381-015-2964-3, indexed in Pubmed: 26584551.

4. A'teriitehau C, Adem C, Levêque C, et al. [Intradiploic parietal meningoencephalocele]. J Radiol. 2004; 85(5 Pt 1): 646-648, indexed in Pubmed: 15205658.

5. Aydin MD. Atretic cephalocele communicating with lateral ventricles. Childs Nerv Syst. 2001; 17(11): 679-680, doi: 10.1007/s003810100499, indexed in Pubmed: 11734987.

6. Ballantyne JW. Manual of antenatal pathology and hygiene; in the embryo. Edinburgh: W. Green and Sons. 1904.

7. Barkovich AJ. Congenital Malformations of the brain and skull. In: Pediatric Neuroimaging (4th ed). Philadelphia: Lippincott Williams \& Wilkins. 2005: 291-439.

8. Bannister CM, Russell SA, Rimmer S, et al. Can prognostic indicators be identified in a fetus with an encephalocele? Eur J Pediatr Surg. 2000; 10 Suppl 1: 20-23, doi: 10.1055/ s-2008-1072408, indexed in Pubmed: 11214826.

9. Bick DS, Brockland JJ, Scott AR. A scalp lesion with intracranial extension. Atretic cephalocele. JAMA Otolaryngol Head Neck Surg. 2015; 141(3): 289-290, doi: 10.1001/ jamaoto.2014.3479, indexed in Pubmed: 25590658.

10. Brunelle F, Baraton J, Renier D, et al. Intracranial venous anomalies associated with atretic cephalocoeles. Pediatr Radiol. 2000; 30(11): 743-747, doi: 10.1007/ s002470000328, indexed in Pubmed: 11100489.

11. Budorick NE, Pretorius DH, McGahan JP, et al. Cephalocele detection in utero: sonographic and clinical features. Ultrasound Obstet Gynecol. 1995; 5(2): 77-85, doi: 10.1046/j.1469-0705.1995.05020077.x, indexed in Pubmed: 7719871.

12. Campbell LR, Dayton DH, Sohal GS. Neural tube defects: a review of human and animal studies on the etiology of neural tube defects. Teratology. 1986; 34(2): 171-187, doi: 10.1002/tera.1420340206, indexed in Pubmed: 3535149.

13. Chapman PH, Swearingen B, Caviness VS. Subtorcular occipital encephaloceles. Anatomical considerations relevant to operative management. J Neurosurg. 1989; 71(3): 375-381, doi: 10.3171/jns.1989.71.3.0375, indexed in Pubmed: 2769389.

14. Cohen MM, Lemire RJ. Syndromes with cephaloceles. Teratology. 1982; 25(2): 161-172, doi: 10.1002/ tera.1420250206, indexed in Pubmed: 7101196.

15. Commens $C$, Rogers $M$, Kan A. Heterotropic brain tissue presenting as bald cysts with a collar of hypertrophic hair. The 'hair collar' sign. Arch Dermatol. 1989; 125(9): 1253-1256, indexed in Pubmed: 2774600.

16. Da Silva SL, Jeelani $Y$, Dang $H a$, et al. Risk factors for hydrocephalus and neurological deficit in children born with an encephalocele. J Neurosurg Pediatr. 2015; 15(4): 392-398, doi: 10.3171/2014.10.PEDS14192, indexed in Pubmed: 25658248.

17. David DJ. Cephaloceles: classification, pathology, and management--a review. J Craniofac Surg. 1993; 4(4): 192-202, indexed in Pubmed: 8110899.

18. Davidson L, Gonzalez-Gomez I, McComb JG. Completely intraosseous atretic meningocele. Pediatr Neurosurg. 2009; 45(4): 308-310, doi: 10.1159/000235606, indexed in Pubmed: 19690448.

19. Drapkin AJ. Rudimentary cephalocele or neural crest remnant? Neurosurgery. 1990; 26(4): 667-73; discussion 674, indexed in Pubmed: 2184377.

20. Friede RL. Anencephaly, rachischisis and encephaloceles. Developmental neuropathology. In: malformations. Springer Verlag, New York. 1975: 230-240.

21. Friede RL. Developmental neuropathology. SpringerVerlag, New York. 1989: 31-34.

22. Goldstein RB, LaPidus AS, Filly RA. Fetal cephaloceles: diagnosis with US. Radiology. 1991; 180(3): 803-808, doi: 10.1148/radiology.180.3.1871297, indexed in Pubmed: 1871297.

23. Hall JG, Friedman JM, Kenna BA, et al. Clinical, genetic, and epidemiological factors in neural tube defects. Am J Hum Genet. 1988; 43(6): 827-837, indexed in Pubmed: 3195584.

24. Hsu SW, Chaloupka JC. Atretic parietal cephalocele associated with sinus pericranii: embryological consideration. Brain Dev. 2012; 34(4): 325-328, doi: 10.1016/j.braindev.2011.06.006, indexed in Pubmed: 21741191.

25. Ingraham F, Swan H. Spina bifida and cranium bifidum. N Engl J Med. 1943; 228(18): 559-563, doi: 10.1056/ nejm194305062281801.

26. James CC, Lassman LP. Spina bifida occulta. In:, Lassman LP (ed). Spinal Dysraphism. (1st ed) Butterworths, London. 1972: 89-97.

27. Jeanty $P$, Shah $D$, Zaleski $W$, et al. Prenatal diagnosis of fetal cephalocele: a sonographic spectrum. Am J Perinatol. 1991; 8(2): 144-149, doi: 10.1055/s-2007-999364, indexed in Pubmed: 2006942.

28. Karch SB, Urich H. Occipital encephalocele: a morphological study. J Neurol Sci. 1972; 15(1): 89-112, indexed in Pubmed: 5008718.

29. Lo BWY, Kulkarni AV, Rutka JT, et al. Clinical predictors of developmental outcome in patients with cephaloceles. J Neurosurg Pediatr. 2008; 2(4): 254-257, doi: 10.3171/ PED.2008.2.10.254, indexed in Pubmed: 18831658.

30. Lorber J. The prognosis of occipital encephalocele. Dev Med Child Neurol. 2008; 9: 75-86, doi: 10.1111/j.14698749.1967.tb02385.x. 
31. Mahajan C, Rath GP, Bithal PK, et al. Perioperative management of children with giant encephalocele: a clinical report of 29 cases. J Neurosurg Anesthesiol. 2017; 29(3): 322-329, doi: 10.1097/ANA.0000000000000282, indexed in Pubmed: 26841351.

32. Martinez-Lage JF, Sola J, Casas C, et al. Atretic cephalocele: the tip of the iceberg. J Neurosurg. 1992; 77(2): 230-235, doi: 10.3171/jns.1992.77.2.0230, indexed in Pubmed: 1625010.

33. Martínez-Lage JF, Capel A, Costa TR, et al. The child with a mass on its head: diagnostic and surgical strategies. Childs Nerv Syst. 1992; 8(5): 247-252, indexed in Pubmed: 1394263.

34. Martínez-Lage JF, Poza M, Sola J, et al. The child with a cephalocele: etiology, neuroimaging, and outcome. Childs Nerv Syst. 1996; 12(9): 540-550, indexed in Pubmed: 8906370.

35. McLaurin RL. Parietal cephaloceles. Neurology. 1964; 14: 764-772, indexed in Pubmed: 14206568.

36. Mealey J, Dzenitis AJ, Hockey AA. The prognosis of encephaloceles. J Neurosurg. 1970; 32(2): 209-218, doi: 10.3171/ jns.1970.32.2.0209, indexed in Pubmed: 5411997.

37. Morioka T, Hashiguchi K, Samura K, et al. Detailed anatomy of intracranial venous anomalies associated with atretic parietal cephaloceles revealed by high-resolution 3D-CISS and high-field T2-weighted reversed MR images. Childs Nerv Syst. 2009; 25(3): 309-315, doi: 10.1007/s00381008-0721-6, indexed in Pubmed: 18839185.

38. Naidich TP, Altman NR, Braffman BH, et al. Cephaloceles and related malformations. AJNR Am J Neuroradiol. 1992; 13(2): 655-690, indexed in Pubmed: 1566723.

39. Osborn AG. Brain development and congenital malformation. In: Diagnostic Neuroradiology (ed). Mosby Year Book. 1994: 3-116.

40. Paetau A, Salonen R, Haltia M. Brain pathology in the Meckel syndrome: a study of 59 cases. Clin Neuropathol. 1985; 4(2): 56-62, indexed in Pubmed: 3995807.

41. Patterson RJ, Egelhoff JC, Crone KR, et al. Atretic parietal cephaloceles revisited: an enlarging clinical and imaging spectrum? AJNR Am J Neuroradiol. 1998; 19(4): 791-795, indexed in Pubmed: 9576676.

42. Patil AA, Etemadrezaie H. Posttraumatic intradiploic meningoencephalocele. Case report. J Neurosurg. 1996; 84(2): 284-287, doi: 10.3171/jns.1996.84.2.0284, indexed in Pubmed: 8592236.

43. Peters J, Raab P, Marquardt G, et al. Intradiploic meningoencephalocele. Eur Radiol. 2002; 12 Suppl 3: S25-S27, doi: 10.1007/s00330-002-1449-4, indexed in Pubmed: 12522596.

44. Quintero RA, Abuhamad A, Hobbins JC, et al. Transabdominal thin-gauge embryofetoscopy: a technique for early prenatal diagnosis and its use in the diagnosis of a case of Meckel-Gruber syndrome. Am J Obstet Gynecol. 1993; 168(5): 1552-1557, indexed in Pubmed: 8498442.

45. Ramadani HM, Nasrat HA. Prenatal diagnosis of recurrent Meckel syndrome. Int J Gynaecol Obstet. 1992; 39(4): 327-332, indexed in Pubmed: 1361467.

46. Sertié AL, Quimby M, Moreira ES, et al. A gene which causes severe ocular alterations and occipital encephalocele (Knobloch syndrome) is mapped to 21q22.3. Hum Mol Genet. 1996; 5(6): 843-847, indexed in Pubmed: 8776601.

47. Sepulveda W, Wong AE, Andreeva E, et al. Sonographic spectrum of first-trimester fetal cephalocele: review of 35 cases. Ultrasound Obstet Gynecol. 2015; 46(1): 29-33, doi: 10.1002/uog.14661, indexed in Pubmed: 25195877.

48. Simpson DA, David DJ, White J. Cephaloceles: treatment, outcome, and antenatal diagnosis. Neurosurgery. 1984; 15(1): 14-21, indexed in Pubmed: 6472590.

49. Şengöz A, Kaya $M$, Yildirim $C H$, et al. Atretic cephalocele in adults. Acta Neurochir (Wien). 2011; 153(11): 2275-2277, doi: 10.1007/s00701-011-1119-x, indexed in Pubmed: 21842442.

50. Urich $\mathrm{H}$. Malformations of the nervous system, perinatal damage and related conditions in early life. In: Blackwood W, Corsellis JAN (ed). Greenfield's neuropathology. Yearbook, Chicago. 1976: 377-469.

51. Warkany J. Congenital malformations: notes and comments. Year Book Medical Publ, Chicago. 1971: 211-216.

52. Willner $A$, Kantrowitz $A B$, Cohen AF. Intrasphenoidal encephalocele: diagnosis and management. Otolaryngol Head Neck Surg. 1994; 111(6): 834-837, doi: 10.1177/ 019459989411100624 , indexed in Pubmed: 7991268.

53. Yeoh GP, Bale PM, de Silva M. Nasal cerebral heterotopia: the so-called nasal glioma or sequestered encephalocele and its variants. Pediatr Pathol. 1989; 9(5): 531-549, indexed in Pubmed: 2813200.

54. Yilmaz O, Oztekin P, Turan A, et al. Recurrent atretic parietal cephalocele in adult and radiological findings. Eurasian J Med. 2012; 44(1): 58-59, doi: 10.5152/eajm.2012.13, indexed in Pubmed: 25610208.

55. Yokota A, Matsukado Y, Fuwa I, et al. Anterior basal encephalocele of the neonatal and infantile period. Neurosurgery. 1986; 19(3): 468-478, indexed in Pubmed: 3762899.

56. Yokota A, Kajiwara H, Kohchi M, et al. Parietal cephalocele: clinical importance of its atretic form and associated malformations. J Neurosurg. 1988; 69(4): 545-551, doi: 10.3171/ jns.1988.69.4.0545, indexed in Pubmed: 3418387.

57. Zinreich SJ, Borders JC, Eisele DW, et al. The utility of magnetic resonance imaging in the diagnosis of intranasal meningoencephaloceles. Arch Otolaryngol Head Neck Surg. 1992; 118(11): 1253-1256, indexed in Pubmed: 1418906. 